\title{
En kvinne i 60-årene med kombinert anemi
}

\author{
Diagnostikk og behandling av anemi ved systemsykdommer kan være \\ utfordrende. Vi presenterer sykehistorien til en kvinne med anemi som \\ viste seg å ha flere ulike årsaker. Et stort transfusjonsbehov ble mar- \\ kant redusert ved behandling med somatostatin.
}

Se kommentar side 968

\author{
Svein-0skar Frigstad* \\ svein.oskar.frigstad@vestreviken.no \\ Medisinsk avdeling \\ Viggo Jønsson \\ Hematologisk avdeling \\ Bjørn Moum \\ Gastromedisinsk avdeling \\ Oslo universitetssykehus

\section{Medisinsk avdeling \\ Bærum sykehus} \\ * Nåværende adresse
}

Pasienten var i slutten av 60-årene da hun ble henvist fra fastlegen til hematologisk avdeling på grunn av alvorlig anemi med hemoglobin 7,8 g/100 ml (11,7-15,2 g/100 ml). Den uttalte anemien hadde utviklet seg langsomt over det siste halve året, og eneste symptom var anemirelatert tretthet. Hun hadde ikke organspesifikke symptomer og hadde ikke observert blødninger. Ved innleggelsen hadde hun blodtrykk 160/90 mm $\mathrm{Hg}$, regelmessig puls $80 / \mathrm{min}$ og temperatur $36,9^{\circ} \mathrm{C}$. Det ble ved klinisk undersøkelse palpert en forstørret lever $3 \mathrm{~cm}$ under høyre kostalbue. Milten var ikke forstørret. Den somatiske undersøkelsen var ellers upåfallende, og det ble ikke funnet noen forstørrede lymfeknuter. Ti år tidligere hadde hun fått behandling med syrehemmer for et helicobacternegativt ulcus duodeni, men ved den aktuelle innleggelsen hadde hun ingen ulcussymptomer. De siste åtte årene hadde hun fått behandling for hypertensjon med en angiotensin II-reseptorantagonist. Hun hadde røykt ti sigaretter daglig i 40 år, men hadde sluttet tre år tidligere. Inntaket av alkohol var moderat med 2 alkoholenheter (24 $\mathrm{g}$ alkoholl) per uke. Utover anemi var orienterende blodprøver upåfallende.

Anemi betegner i praksis redusert hemoglobinkonsentrasjon i perifert blod. Årsaken kan være produksjonssvikt i beinmargen, $ø \mathrm{kt}$ tap av erytrocytter ved blødning eller økt nedbrytning ved hemolyse. I den kliniske hverdag er en morfologisk inndeling i mikrocytær, normocytær og makrocytær anemi nyttig. Mikrocytær anemi ses hovedsakelig ved jernmangel, kronisk blødning og talassemi. Makrocytær anemi ses typisk ved mangeltilstander (vitamin $\mathrm{B}_{12}$-mangel og folatmangel), aldersbetinget atrofi av ventrikkelslimhinnen, i lette grader ved myelodysplasi og under autoimmun hemolyse. Årsaker til normocytær anemi kan blant annet være kronisk inflammasjon (såkalt anemi ved kronisk sykdom), nyresykdom eller lett autoimmun hemolyse. Anemi er ikke sjelden normocytær i tidlig fase av anemi av de fleste årsaker. Videre kan kombinert anemi, det vil si anemi av flere samtidige årsaker, gi et ukarakteristisk bilde.

Vår pasient hadde tre år tidligere fått diagnosen autoimmun hemolytisk anemi av varmeantistofftype. Anemien var den gang normocytær med MCV $96 \mathrm{fl}$ (82-98 fl), lav haptoglobinkonsentrasjon og forhøyet reticulocyttall, men normalt nivå av laktatdehydrogenase (LD). Direkte antiglobulintest (DAT) var positiv med et komplement C3konsumerende varme lgG-antistoff, det vil si et autoantistoff mot erytrocytter som binder seg med sterkest affinitet omkring kroppstemperatur og initierer hemolyse.

Lavt haptoglobinnivå, forhøyet reticulocyttall og positiv DAT-test er typisk for autoimmun hemolytisk anemi. Om lag $75 \%$ av autoimmune hemolytiske anemier er av varmeantistofftype og opptrer ofte hos pasienter med andre autoimmune sykdommer eller lymfoproliferative tilstander $(1,2)$. Tilstanden ble hos vår pasient oppdaget da hun var innlagt i medisinsk avdeling med icterus og akutt debut av autoimmun hepatitt.

Hun hadde ved denne innleggelsen forhøyede nivåer av levertransaminaser og alkalisk fosfatase. Bilirubin var 44 umol/l (5-25 $\mu \mathrm{mol} / \mathrm{ll}$, immunglobulin $G$ (lgG) var kraftig forhøyet, og det var positivitet for antinukleære antistoffer (ANA) og antistoffer mot glatt muskulatur. Leverbiopsi viste inflam- masjon med uttalt interfaseaktivitet og brodannende fibrose forenlig med autoimmun hepatitt.

Lett forhøyet bilirubinnivå kunne dels forklares ved intrahepatisk gallestase og dels ved hemolyse. Det ble ikke undersøkt spesielt for konjugert eller ukonjugert hyperbilirubinemi. Anemien var forklart ved autoimmun hemolyse, en tilstand som kan være assosiert med autoimmun hepatitt (2). Anemien var normocytær, og det var ikke kliniske tegn til kronisk blødning hvor man ville forvente mikrocytær anemi. På grunn av behov for langvarig behandling med prednisolon hos pasient med tidligere ulcussykdom, ble gastroskopi utført som ledd i utredningen. Videre hadde hun kjent familiær opphopning av brystkreft og tykktarmskreft og gjennomgikk koloskopi regelmessig hvert tredje til femte år.

Gastroskopi på dette tidspunkt viste normale forhold, mens det ved koloskopi ble påvist en angiodysplasi i coecum og divertikler icolon sigmoideum. Angiodysplasi er en karmalformasjon som kan blø intermitterende, men det ble ved undersøkelsen ikke sett tegn til aktiv blødning. Hemofec $i$ avføring var negativ.

Hun fikk standardbehandling for autoimmun hepatitt med kombinasjon av prednisolon og azatioprin (3). Azatioprin ble kun gitt kortvarig grunnet bivirkninger. Under behandling fikk hun normalisering av levertransaminaser og IgG. Behandling med steroider er førstelinjebehandling også ved autoimmun hemolytisk anemi av varmeantistofftype, og hun fikk vedlikeholdsbehandling med prednisolon $5 \mathrm{mg}$ daglig som monoterapi (1). Hun ble utskrevet og første året fulgt med jevnlige kontroller ved gastromedisinsk poliklinikk og deretter hos fastlegen.

Under behandling med prednisolon hadde hun i nesten tre år stabile hemoglobinverdier over $10 \mathrm{~g} / 100 \mathrm{ml}$. Verdiene både for bilirubin og haptoglobin ble normalisert, og således var det ikke sikre tegn til aktiv hemolyse. MCV var normal eller lett forhøyet. DAT-test var negativ i flere prøver. Levertransaminaser og lgG, som følges under behandling for autoimmun hepatitt, holdt seg innen normalområdet.

Forut for den aktuelle henvisning for anemi, hadde pasienten selvadministrert perorale 
jerntilskudd i flere måneder, noe som kan ha bidratt til forsinkelse av videre anemidiagnostikk.

Ved den aktuelle innleggelsen var DAT-testen igjen positiv, og det var lett reticulocytose samt haptoglobin i nedre normalområde $0,9 \mathrm{~g} / \mathrm{l}(0,4-2,1 \mathrm{~g} / \mathrm{l})$. Hemofec var negativ. Hun brukte fortsatt prednisolon som vedlikeholdsbehandling. Dosen ble økt til 40 mg daglig, og hun fikk to blodtransfusjoner.

Blodbildet passet med residiv av autoimmun hemolytisk anemi. Anemien hadde utviklet seg over tid, og allmenntilstanden var rimelig god. Hun ble utskrevet, og den videre utredning og behandling ble gjort poliklinisk som dagpasient ved hematologisk dagavdeling.

Ved kontroll på hematologisk poliklinikk to måneder senere hadde hemoglobinkonsentrasjonen falt ytterligere til 4,8 g/d. MCV var $90 \mathrm{fl}$, og anemien var fortsatt normocytær. Hemofec var fremdeles negativ.

Pasienten ble på dette tidspunkt grundig utredet for assosierte tilstander. Spesielt var det viktig å utelukke lymfoproliferativ tilstand eller annen systemsykdom assosiert med autoimmun hemolytisk anemi. Kronisk lymfatisk leukemi er den lymfoproliferative sykdommen som ses hyppigst sammen med autoimmun hemolytisk anemi (1).

Aspirat og biopsi fra beinmarg viste en reaktiv økt erytropoese kompensatorisk til hemolyse, men ikke tegn til annen beinmargssykdom. Serum-elektroforese var normal uten monoklonal komponent. Væskestrømscytometri for monoklonale lymfocyttpopulasjoner i blod og beinmarg ga ingen holdepunkter for lymfoproliferativ sykdom. Computertomografi (CT) av collum, thorax og abdomen viste ingen patologiske lymfeknuter, og milt og lever var normale. Det var heller ingen gallestein til tross for tidligere hemolyse. Det var ikke serologiske holdepunkter for systemisk lupus erythematosus (SLE), pernisiøs anemi eller tyreoiditt som kan være assosiert til autoimmun hemolytisk anemi av varmeantistofftype $(2,3)$. Cøliaki var tidligere utelukket med normale tynntarmsbiopsier.

Høydose intravenøst immunglobulin er veldokumentert annenlinjebehandling ved autoimmun hemolytisk anemi av varmeantistofftype ved manglende steroidrespons (1).

I en periode på ti uker ble det derfor i tillegg til prednisolon $40 \mathrm{mg}$ daglig, gitt høydose intravenøst polyklonalt humant gammaglobulin IgG for å redusere hemolyse. Hemoglobin var etter behandling $6,9 \mathrm{~g} / 100 \mathrm{ml}$ MCV $76 \mathrm{fl}$, jern $4 \mu \mathrm{mol} / \mathrm{l}(9-34 \mu \mathrm{mol} / \mathrm{ll}), \mathrm{TIBC}$ $99 \mu \mathrm{mol} / \mathrm{l}(49-83 \mu \mathrm{mol} / \mathrm{l})$ og ferritin $6 \mu \mathrm{g} / \mathrm{l}$ $(10-200 \mu \mathrm{g} / \mathrm{l})$. Verdiene for vitamin $B_{12}$ (kobalamin) og folat var normale uten substitusjon. Det var ingen tegn til hemoragisk diatese eller generell blødningstendens med normale trombocyttall og koagulasjonsstatus. Hun hadde stabil vekt og inntok normal kost.

Pasienten hadde persisterende alvorlig anemi, selv om DAT-testen var blitt negativ og de øvrige hemolyseparametrene normali- sert. Anemien var mikrocytær og ikke lett makrocytær som vi ville ventet med autoimmun hemolyse. Kronisk blødning ble mistenkt som kompliserende årsak til anemi.

I de følgende uker tilkom flere episoder med diffuse magesmerter og melena med samtidige fall i hemoglobinkonsentrasjonen til laveste verdi $6,1 \mathrm{~g} / 100 \mathrm{ml}$. Hemofec var positiv i gjentatte prøver. Det ble gjort en gjennomgang for å avklare blødningsfokus. Gastroskopi var igjen normal uten påvist blødningsfokus. Angiodysplasien som tidligere var sett i coecum, lot seg ikke reprodusere ved gjentatt koloskopi på et tidspunkt hvor hun ikke hadde tegn til aktiv tarmblødning. Imidlertid kunne blødende tumor utelukkes som årsak. Kapselvideoenteroskopi av tynntarm påviste ikke blødningsfokus. Analyser av urin var negative for blod, og hun hadde anamnestisk ingen underlivsblødning.

Det intermitterende blødningsmønsteret hos vår pasient er typisk ved blødning fra angiodysplasi i tarm $(4,5)$. Blødningsårsaken kunne ikke korrigeres endoskopisk eller kirurgisk da man ikke sikkert kunne påvise den aktuelle blødningskilden. Dette er et klassisk problem ved angiodysplasi. Endoskopisk eller kirurgisk intervensjon er dessuten usikker, fordi $40-60 \%$ av alle med endoskopiske funn av angiodysplasi i tarm vil ha flere angiodysplasier lokalisert andre steder i tarmkanalen (5). Dette medfører at lokalisert behandling vanskeliggjøres og ofte ikke er effektiv.

Pasienten hadde grunnet intermitterende blødning med melena ledsaget av fall $i$ he-

Antall blodtransfusjoner

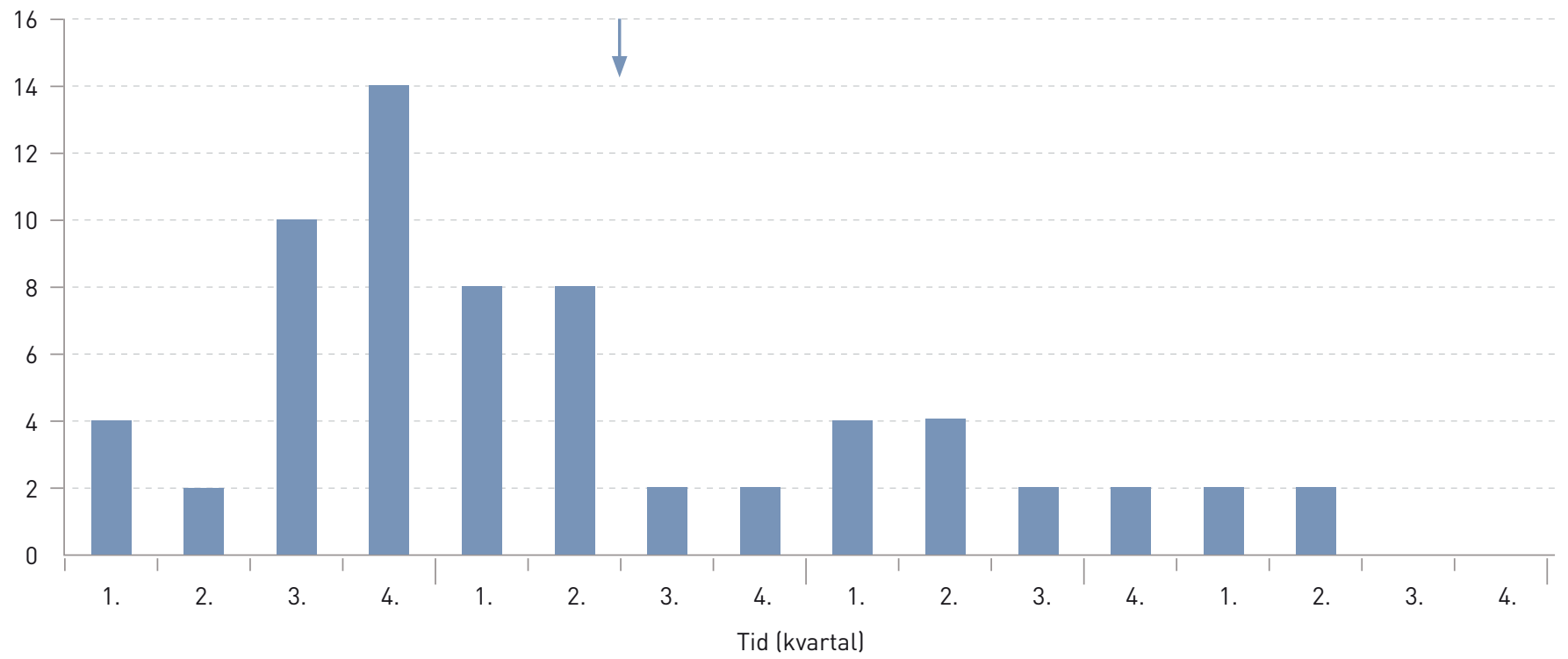

Figur 1 Antall blodtransfusjoner per kvartal før og etter oppstart med somatostatinanalog (pil). Før behandling varierte hemoglobinkonsentrasjonen mellom 8 og 10 g/dl etter transfusjoner. Etter oppstart med somatostatinanalog har hemoglobin stort sett ligget mellom 10 og $11 \mathrm{~g} / \mathrm{dl}$, med kun sjeldne symptomgivende fall i hemoglobin under dette nivå som har ført til blodtransfusjon. (ikke vist på figuren) 
moglobinkonsentrasjon, et økende behov for blodtransfusjoner ofte flere ganger per måned (fig 1). Hun utviklet imidlertid irregulære erytrocyttantistoffer, blant annet antiA1 og spor av antistoff uten sikker spesifisitet, og det ble vanskeligere å finne forlikelig blod.

Med dette oppsto i tillegg alloimmunisering som en mulig anemimekanisme da blodtransfusjoner kan etterfølges av danning av autoantistoff (1). Det kan være vanskelig å finne fullt forlikelig blod til pasienter med autoimmun hemolytisk anemi på grunn av tilstedeværelse av antistoffer som vanligvis reagerer med antigen til stede på røde blodceller hos de fleste individer i en donorpopulasjon. Det er kjent at pasienter med underliggende autoimmun hemolytisk anemi av varmeantistofftype har økt risiko for transfusjonskomplikasjoner og ytterligere aktivering av immunsystemet ved transfusjon (6). Hos vår pasient tilkom imidlertid ingen alvorlige transfusjonskomplikasjoner.

Til tross for hyppige transfusjoner var det ingen økt jernavleiring med vedvarende lav ferritinverdi, noe som stemmer godt med kronisk blødning fra tarm. Det ble forsøkt traneksamsyre $500 \mathrm{mg}$ tre ganger daglig i nesten ni måneder uten nevneverdig effekt. Etter vel et år ble det gitt oppstartsbehandling med octreotid $100 \mu \mathrm{g} \times 3$ daglig subkutant $i$ en uke og deretter octreotid acetat 20 mg intramuskulært hver fjerde uke.

Dette behandlingsregimet er tidligere beskrevet i form av kasuistikker i litteraturen hvor somatostatinanalog er gitt på tilsvarende indikasjon $(7,8)$. Somatostatinanaloger benyttes for å redusere blødning fra oesophagusvaricer ved portal hypertensjon. Virkningsmekanismen antas å være vasokonstriksjon i splanchnicusområdet via hemming av vasoaktive hormoner, og tilsvarende effekt kan foreligge ved angiodysplasier (7)

Transfusjonsbehovet ble markant redusert under behandling med somatostatinanalog (fig 1), og situasjonen har holdt seg stabil under fortsatt observasjon $i$ halvannet år. Hemoglobinkonsentrasjonen har etter oppstart med somatostatinanalog vært over $10 \mathrm{~g} / 100 \mathrm{ml}$ med kun sjeldne symptomgivende fall under dette nivå som medførte at hun fikk blodtransfusjon. Pasienten har ikke hatt bivirkninger av behandlingen. Så lenge pasientens tilstand har vært stabil, har det ikke vært aktuelt med ytterligere utredning, og hun får nå en sjelden gang transfusjoner ved behov.

\section{Diskusjon}

Flere samtidige anemityper hos samme pasient kan være utfordrende å diagnostisere. Vår pasient hadde kombinert anemi med både autoimmun hemolyse, kronisk blødning og alloimmunisering. Det røde blodbil- det var ikke helt typisk da autoimmun hemolytisk anemi ble diagnostisert. Ved autoimmun hemolyse vil man forvente lett makrocytose med forhøyet MCV-verdi, men det gjennomsnittlige cellevolumet var normalt. Det kan skyldes samtidig anemi ved kronisk sykdom da pasienten hadde samtidig autoimmun hepatitt. Anemi ved kronisk sykdom er en normocytær anemiform med retensjon av jern i det retikuloendoteliale system på grunn av inflammasjon (9). En annen forklaring på normal $\mathrm{MCV}$-verdi er en mikrocytær komponent fra blødning, for eksempel tidlig manifestasjon av intermitterende blødning fra angiodysplasi.

Sykehistorien viser at jerntilskudd ved anemi uten en forutgående grundig diagnostisk avklaring kan forsinke og komplisere anemidiagnostikken siden en blødning da vil bruke lengre tid på å manifestere seg ved tomme jerndepoter. Dette kan ha alvorlige konsekvenser i tilfeller der blødningskilden for eksempel er en malign tumor. Det er viktig at årsaken til anemi er avklart før det gis jerntilskudd.

Autoimmune sykdommer er ofte konkomitante, det vil si at pasienten har flere samtidige autoimmune sykdommer. Hos vår pasient ble autoimmun hemolytisk anemi første gang påvist da hun var innlagt med autoimmun hepatitt. Det er viktig og klinisk svært relevant å utelukke andre assosierte tilstander når én allerede er påvist. En bred utredning er ofte betydningsfull fordi behandlingen kan være ulik ved konkomitante tilstander. Autoimmun hemolytisk anemi av varmeantistofftype kan være assosiert med lymfoproliferative tilstander og er svært viktig å utelukke (1).

Til tross for intensiv blodtransfusjon over lang tid fikk vår pasient under samtidig steroidbehandling ingen alvorlige transfusjonskomplikasjoner. Imidlertid ble det vanskeligere å finne forlikelig blod. Pasienter med autoimmun hemolyse bør transfunderes på strenge indikasjoner da disse pasientene er spesielt utsatt for alloimmunisering. Før transfusjon bør det foretas en utvidet pretransfusjonsutredning for å finne fenotypisk forlikelig blod og autoabsorpsjonsteknikker benyttes for å redusere autoantistoffet mot erytrocytter (6).

Angiodysplasier er en viktig årsak til blødninger i tarmkanalen og antas å forårsake $2-8 \%$ av tarmblødninger $(7,8)$. Somatostatinanalog kan ved blødning fra angiodysplasier være et alternativ i behandling av transfusjonstrengende alvorlig anemi hvor annen kirurgisk, endoskopisk eller medikamentell behandling ikke er noe alternativ eller uvirksomt. Hos vår pasient ser dette ut til å ha redusert behovet for blodtransfusjoner i betydelig grad. Komplikasjoner ved stadige blodtransfusjoner over tid som fortsatt alloimmunisering og risiko for jernopphopning, ble på denne måten unngått.

Hormonbehandling med østrogen har vært forsøkt for å redusere blødning fra an- giodysplasier, men var ikke aktuelt hos vår pasient grunnet kreftrisiko (10).

Octreotidacetat gis som månedlig behandling og er et praktisk alternativ som kan gi bedret livskvalitet og redusere komplikasjoner ved stadig gjentatte blodtransfusjoner. Problemet er at behandlingen ikke eliminerer angiodysplasien og at erfaringen med behandlingen ennå er sparsom. Ingen kjenner varighet av den oppnådde hemostasen eller hvilke pasienter som er best egnet. $\mathrm{Vi}$ tror at flere pasienter kan ha nytte av en slik behandling da angiodysplasier med blødningsanemi ikke er noe sjeldent forekommende fenomen og kurativ behandling ofte er vanskelig.

Pasienten har gitt samtykke til at artikkelen blir publisert.

Vi takker Lars Østegård Kristensen, Medicinsk endokrinologisk avdeling, Herlev Hospital, Danmark for råd og hjelp med behandlingen, Birgit Skjelvik, Oslo universitetssykehus for hjelp med utarbeiding av figur og Karianne Larsen, Sentrallaboratoriet, Oslo universitetssykehus, Aker for hjelp med innhenting av data for blodtransfusjoner.

\section{Svein-Oskar Frigstad (f. 1975)}

er spesialist i indremedisin og i fordøyelsessykdommer. Han arbeider nå som overlege ved Medisinsk avdeling, Bærum sykehus.

Forfatter har fylt ut ICMJE-skjemaet og oppgir ingen interessekonflikter.

\section{Viggo Jønsson (f. 1947)}

er professor i hematologi ved Universitetet i Oslo. Maligne blodsykdommer og cancergenetikk er kliniske og vitenskapelige hovedområder.

Forfatter har fylt ut ICMJE-skjemaet og oppgir ingen interessekonflikter.

\section{Bjørn Moum (f. 1952)}

er spesialist i indremedisin og i fordøyelsessykdommer. Han er seksjonsleder for FoU Gastromedisinsk avdeling, Oslo universitetssykehus og professor ved Universitetet i Oslo. Forfatter har fylt ut ICMJE-skjemaet og oppgir ingen interessekonflikter.

\section{Litteratur}

1. Berentsen S, Sundic T, Hervig T et al. Autoimmun hemolytisk anemi. Tidsskr Nor Legeforen 2009. 129: 2226-31.

2. Bittencourt PL, Farias $A Q$, Porta $G$ et al. Frequency of concurrent autoimmune disorders in patients with autoimmune hepatitis: effect of age, gender, and genetic background. J Clin Gastroenterol 2008; 42: 300-5.

3. Czaja AJ. Current and future treatments of autoimmune hepatitis. Expert Rev Gastroenterol Hepatol 2009; 3: 269-91.

4. Clouse RE, Costigan DJ, Mills BA et al. Angiodysplasia as a cause of upper gastrointestinal bleeding. Arch Intern Med 1985: 145: 458-61. 
5. Cappell MS. Spatial clustering of simultaneous nonhereditary gastrointestinal angiodysplasia. Small but significant correlation between nonhereditary colonic and upper gastrointestinal angiodysplasia. Dig Dis Sci 1992: 37: 1072-7.

6. Melve GK, Hervig T, Øvrebøe R et al. Blodtransfusjon og pretransfusjonsutgreiing ved autoimmun hemolytisk anemi av varmetype. Tidsskr Nor Lægeforen 2004; 124: 2918-20.
7. Andersen MR, Aaseby J. Somatostatin in the treat ment of gastrointestinal bleeding caused by angiodysplasia. Scand J Gastroenterol 1996; 31: 1037-9.

8. Boesby L, Christensen NJ, Kristensen L $\varnothing$. Behandling av gastrointestinal blødning fra angiodysplasier med somatostatinanalogen octreotid. Ugeskr Laeger 2008; 11: 958

9. Weiss G, Goodnough LT. Anemia of chronic disease. N Engl J Med 2005; 352: 1011-23.
10. Barkin JS, Ross BS. Medical therapy for chronic gastrointestinal bleeding of obscure origin. Am J Gastroenterol 1998; 93: 1250-4.

Mottatt 3.1. 2011, første revisjon innsendt 27.5. 2011, godkjent 26.1. 2012. Medisinsk redaktør Siri Lunde.

\section{Kommentar}

\section{Flere sykdommer med samme kliniske presentasjon}

Hos pasienter som har flere udiagnostiserte sykdommer samtidig, kan diagnostikken være vanskelig. Dersom symptomer og funn ved disse sykdommene er identiske eller overlapper, blir utfordringen ekstra stor. Svein-Oskar Frigstad og medforfattere gir en lærerik beskrivelse av en slik situasjon. De omtaler en person med to sykdommer: autoimmun hemolytisk anemi av varmeantistofftype og kronisk autoimmun hepatitt. $\mathrm{Da}$ hun på ny utviklet sykdom med anemi som klinisk presentasjon, var det nærliggende å tenke på eksaserbasjon av den autoimmune hemolysen. Det forelå imidlertid en tredje tilstand, blødning fra angiodysplasi, og riktig diagnose førte til at pasienten fikk virksom behandling.

Flere sykdommer hos samme pasient kan skyldes tilfeldigheter (koinsidens), assosiasjon (gjerne pga. felles årsak eller risikofaktorer) eller direkte kausal sammenheng (der den ene sykdommen fører til en eller flere andre). Klinikeren bør mistenke flere samtidige sykdommer ved symptomer og funn som ikke lett forklares av den tilstanden man påviser først.

Ved autoimmun hemolytisk anemi er det avgjørende for riktig behandling å kartlegge undergruppe og eventuell assosiert sykdom (1-3). Varmeantistoffmediert autoimmun hemolyse er en polyklonal autoimmun sykdom, dvs. en tilstand der de patogene lymfocyttene ikke tilhører én enkelt celleklon med ensartede geno- og fenotypiske karakteristika. Polyklonale autoimmune sykdommer er hyppig assosiert med hverandre, og ca. $50 \%$ av pasienter med autoimmun hemolytisk anemi av varmeantistofftype har en annen autoimmun eller lymfoproliferativ tilstand i tillegg $(1,2)$. En T-cellemediert, generell immundysfunksjon med suboptimal diskri- minering mellom «selv» og «ikke-selv» antas å ligge til grunn for utvikling av polyklonale autoimmune sykdommer (4). Kronisk lymfatisk leukemi er den sykdommen som hyppigst er forbundet med varmeantistoffmediert hemolyse, men en lang rekke andre assosierte tilstander forekommer, blant annet kronisk autoimmun hepatitt $(1,2)$.

Et mindretall av autoimmune sykdommer er monoklonale, slik som kronisk kuldeagglutininsykdom $(1,3)$ og perifer nevropati ved Waldenströms makroglobulinemi og andre monoklonale IgM-gammopatier (5). Ved slike tilstander blir autoantistoffet produsert direkte av den patologiske B-lymfocyttklonen, og pasienten har ikke noen generell autoimmun disposisjon. Nærmere immunpatologisk karakterisering av den tilgrunnliggende lymfoproliferative tilstanden kan ha differensialdiagnostisk betydning og terapeutiske konsekvenser $(1,3)$. Også polyklonale autoimmune sykdommer kan være forbundet med monoklonale lymfoproliferative tilstander. Assosiasjonen mellom varmeantistoffbetinget autoimmun hemolytisk anemi og kronisk lymfatisk leukemi er allerede nevnt. Flere autoimmune sykdommer er forbundet med økt risiko for non-Hodgkins lymfomer, og risikoen for marginalsonelymfom i glandula parotis er av enkelte forfattere funnet å være inntil 1000 ganger høyere hos pasienter med Sjögrens syndrom enn i normalbefolkningen (6).

Noen store sykdomsgrupper, slik som arteriosklerose, diabetes og lipidforstyrrelser, er så nært knyttet til hverandre at assosiasjonen er velkjent for alle leger. Når to eller flere sjeldnere, autoimmune sykdommer forekommer samtidig, kreves det at klinikeren kjenner til assosiasjonene mellom disse til- standene og bevisst tenker på dem. Kompliseres vurderingen ytterligere av en urelatert sykdom, står legen overfor enda større krav til kunnskap og klinisk årvåkenhet.

\section{Sigbjørn Berentsen}

sigbjorn.berentsen@haugnett.no

Medisinsk klinikk

Haugesund sjukehus

Sigbjørn Berentsen (f. 1948) er dr.med. og spesialist $\mathrm{i}$ indremedisin. Han er seksjonsoverlege ved Medisinsk klinikk, Haugesund sjukehus, fagansvarlig for blodsykdommer i Helse Fonna og førsteamanuensis ved Universitetet i Bergen. Forfatter har fylt ut ICMJE-skjemaet og oppgir ingen interessekonflikter.

Litteratur

1. Berentsen S, Sundic T, Hervig T et al. Autoimmun hemolytisk anemi. Tidsskr Nor Legeforen 2009; 129: 2226-31.

2. Michel M. Classification and therapeutic approaches in autoimmune hemolytic anemia: an update. Expert Rev Hematol 2011; 4: 607-18.

3. Berentsen S, Tjønnfjord GE. Diagnosis and treatment of cold agglutinin mediated autoimmune hemolytic anemia. Blood Rev 2012. e-publisert 11.2.2012. (doi: 10.1016/j.blre.2012.01.002).

4. Ward FJ, Hall AM, Cairns LS et al. Clonal regulatory $T$ cells specific for a red blood cell autoantigen in human autoimmune hemolytic anemia. Blood 2008: 111: 680-7.

5. Nobile-Orazio E. Antigenic determinants in IgM paraprotein-related neuropathies. Clin Lymphoma Myeloma 2009; 9: 107-9.

6. Smedby KE, Askling J, Mariette X et al. Autoimmune and inflammatory disorders and risk of malignant lymphomas-an update. J Intern Med 2008; 264: 514-27.

Mottatt 19.2. 2012, første revisjon innsendt 24.2 2012, godkjent 27.2. 2012. Medisinsk redaktør Siri Lunde. 